\title{
Dialogic Struggle in the Becoming of the Cultural Revolution: Between Elite Conflict and Mass Mobilization
}

Xiaohong $\mathrm{Xu}$, National University of Singapore

\begin{abstract}
This article addresses the becoming of contentious political events through the case of the Chinese Cultural Revolution (1966). The conditional theory of structural causation and the rational choice conception of agency that have complemented each other in current scholarship have left missing links between elite conflict and mass mobilization. Examining the dialogic struggle among various actors involved in the process helps to overcome the teleological explanation of the rise of the Cultural Revolution and brings to light the politics of interpretation in constructing its meaning. The perspective shows ideological contradictions in the status quo ante to be important sources for change in an uncertain and destabilizing situation. The event thus did not result from the realization of actors' fixed goals but was an emergent process of the disarticulation of structural contradictions, in which actors' active appropriation and changing deployment of cultural repertoires were critical.
\end{abstract}

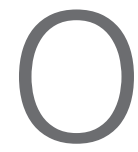

n August 1, 1966, in one of the most pivotal moments in modern political history, Mao Zedong found himself lecturing about the philosophy of history to his colleagues within the top echelons of the Chinese Communist Party (CCP), in order to convince them to make a historic decision. He wanted them to condemn the use of work teams during the previous two months, a policy that they had been used to for decades during mass campaigns. Yet Mao now said that the work teams were obstructing the mass movement of the Cultural Revolution. In this inaugural meeting of the Eleventh Plenary Session of the Eighth Central Committee of the CCP, Chen Boda, Mao's close associate and head of the newly anointed Central Cultural Revolution Group, gave a speech that accused the work

Critical Historical Studies (Fall 2017). () 2017 by The University of Chicago. All rights reserved. 2326-4462/2017/0402-0003\$10.00 
teams of cracking down on student initiatives and estranging themselves from the masses. When he stated, "the Great Proletarian Cultural Revolution is a necessity yet there are many contingencies in great revolutions," Mao interjected: "The necessity is hidden in the contingencies. Who knew that, when Nie Yuanzi put forth that big-character poster, which then was broadcasted, chaos would ensue? It's all because of blind faith, blind faith in your own wisdom and no faith in the wisdom of the masses. In fact we have little wisdom. Workers, peasants and revolutionary intellectuals are wiser than us. We must rely on them. We know nothing." ${ }^{1}$ There were two motives for Mao's interjection. First, he acknowledged the unintendedness and contingencies that students' action brought forth in redefining the project of the Cultural Revolution; second, he tried to sway the doubters by casting a sense of inevitability about his push to withdraw the work teams and endorse the militant students' rebellion. His colleagues eventually conformed by passing the "Decision concerning the Great Proletarian Cultural Revolution" (the "Sixteen Points") on August 8 . For Mao, "the necessity is hidden in the contingencies" because the necessity of history in general and the Cultural Revolution in particular is realized only through actors' "correct" response to the unfolding contingencies-and, in this case, his.

This subtle tension that Mao announced between contingencies and necessity, however, has been lost in the teleological narrative that dominates the existing literature. The dominant narrative attributes the Cultural Revolution merely to the preexisting conflict between Mao and the party bureaucracy. This article, by contrast, addresses a question that has been obscured by the teleological narrativethe question of the "becoming" of the Cultural Revolution, that is, the interactive process between Mao, party officials, and students through which the Cultural Revolution was transformed from a Stalinist purge to a mass rebellion under the slogan "rebellion is justified" (zaofan youli).

The process of becoming is a crucial issue during disruptive and destabilizing historical events. Historical social scientists have increasingly drawn attention to symbolic and strategic interactive processes as part and parcel of social transformations, through which old institutions break down and new repertoires of action acquire valence. ${ }^{2}$

1. Pang Xianzhi and Jin Chongji, eds., Mao Zedong zhuan, 1949-1976 [The biography of Mao Zedong] (Beijing: Zhongyang wenxian chubanshe, 2003), 2:1426. Unless otherwise noted, all translations are my own.

2. Marshall D. Sahlins, Historical Metaphors and Mythical Realities: Structure in the Early History of the Sandwich Islands Kingdom (Ann Arbor: University of Michigan Press, 2009); William H. Sewell Jr., "Historical Events as Transformations of Structures: Inventing Revolution at the Bastille," Theory and Society 25 (December 1996): 841-81; Robin Wagner-Pacifici, Theorizing the Standoff: Contingency in Action (Cambridge University Press, 2000); Ivan Ermakoff, "The Structure of Contingency," American Journal of Sociology 121, no. 1 (2015): 64-125; Isaac Ariail Reed, "Between Structural Breakdown and Crisis Action: Interpretation in the Whiskey Rebellion and the Salem Witch Trials," Critical Historical Studies 3, no. 1 (2016): 27-64. 
In one sense, the purpose of this article is to extend this emerging agenda to an analysis of the Chinese Cultural Revolution. On the other hand, because the way the existing Cultural Revolution literature papers over its becoming also characterizes common blind spots in the analyses of other contentious political events, this case study also throws into the sharp relief the added value of the cultural analytical approach over competing modes of explanation-particularly the structural conditional theory of causation and the rationalist conception of agency.

In order to capture the becoming of the Cultural Revolution, it behooves us to ask, first, why elite conflict within the party-state was able to catalyze student rebellion and, second, why student rebellion in turn aggravated elite division. To address these questions, I draw on and advance two theoretical strands: the perspective of "dialogic struggle" in collective action, which Marc Steinberg developed from Mikhail Bakhtin's social semiotics, ${ }^{3}$ which helps to explicate the dialogic processes between elite conflict and mass mobilization, and William Sewell's theory of ideological contradictions as sources of social transformations, ${ }^{4}$ which sheds light on the mechanisms of cultural appropriation that unraveled the hegemonic discourse of the Stalinist partystate and gave rise to the new political configuration of Maoists aligned with rebel students against the party bureaucracy. In doing so, I make use of party documents, Red Guard publications, and, more importantly, memoirs of many students who were deeply involved in the emergence of the Cultural Revolution.

Before I delve into these questions, it is necessary to first clear the ground by examining the literature on the Cultural Revolution and explaining how its theoretical underpinnings have left unsolved puzzles and staved off the question of the "becoming" of the Cultural Revolution.

\section{BETWEEN CAUSE AND PROCESS}

The existing literature divides the cause and process of the Cultural Revolution into two separate stages and treats them as two separate questions. Its cause, it is assumed, is a question that is already settled and not worth asking; instead, what the scholarship is overwhelmingly concerned with is its process/outcome, particularly factional formation. Andrew Walder, for example, claims that "the enduring puzzle about the Red Guards is not the perennial preoccupation of students of con-

3. Marc W. Steinberg, "The Talk and Back Talk of Collective Action: A Dialogic Analysis of Repertoires of Discourse among Nineteenth-Century English Cotton Spinners," American Journal of Sociology 105, no. 3 (1999): 736-80.

4. William H. Sewell Jr., "Ideologies and Social Revolutions: Reflections on the French Case," Journal of Modern History 57, no. 1 (March 1, 1985): 57-85, "A Theory of Structure: Duality, Agency, and Transformation," American Journal of Sociology 98, no. 1 (1992): 1-29, and "Historical Events as Transformations of Structures." 
tentious politics-how insurgents are able to mobilize adherents to make claims against the existing polity," because apparently "the Red Guard movement was instigated from the apex of the political system" and "facilitated from the beginning by access to the mass media, funding, means of transportation and communication, and the support and advice of a powerful leadership faction." Rather, "the real puzzle is why politically active students were divided into factions" after political elites set the movement in motion. ${ }^{5}$

As Jeffrey Paige points out, to temporally divide cause and process/outcome into two separate questions is an unexceptional but questionable scholarly practice, epitomized by Theda Skocpol's State and Social Revolutions, because it tends to reduce causal explanation to identifying variables of initial structural conditions and posits two separate sets of variables to explain the cause and outcome of, for example, social revolutions. ${ }^{6}$ This practice also applies to the Cultural Revolution scholarship: it attributes its cause to elite conflict (between Mao and the party officialdom) as a sufficient explanation and concentrates on explaining one feature of its process/ outcome: Red Guard factionalism. ${ }^{7}$ What makes this literature characteristically interesting is how the two complement each other. While the initial condition of elite conflict is held as the standard account for the cause of the Cultural Revolution, the dominant mode of explanation for Red Guard factionalism is premised on a rational choice conception of individual agency. Thus, initial conditions seem to make peace with the rational actor's agency in the movement through this temporal division.

\section{THE CAUSE}

Specifically, scholars have searched for the cause of the Cultural Revolution in the conflicting policy styles and preferences between Mao and his party comrades after 1962, when Mao stepped down from the first front of managing the party-state and retreated to the second front in charge of ideological guidance, while his lieutenants, such as Liu Shaoqi and Deng Xiaoping, took over the first-front duty. ${ }^{8}$ In this

5. Andrew Walder, "Ambiguity and Choice in Political Movements: The Origins of Beijing Red Guard Factionalism," American Journal of Sociology 112, no. 3 (2006): 712

6. Jeffery M. Paige, "Conjuncture, Comparison, and Conditional Theory in Macrosocial Inquiry," American Journal of Sociology 105, no. 3 (1999): 781-800.

7. An important exception is Yi-Ching Wu's examination of the dynamics of ideological transgression in the movement. Yiching Wu, The Cultural Revolution at the Margins: Chinese Socialism in Crisis (Cambridge, MA: Harvard University Press, 2014). Also, see Joel Andreas, "The Structure of Charismatic Mobilization: A Case Study of Rebellion during the Chinese Cultural Revolution," American Sociological Review 72, no. 3 (2007): 434-58.

8. Roderick MacFarquhar, The Origins of the Cultural Revolution, vol. 3 (Oxford: Oxford University Press, 1997); Lowell Dittmer, Liu Shao-Chi and the Chinese Cultural Revolution: The Politics of Mass Criticism (Berkeley: University of California Press, 1982). 
account, the Cultural Revolution was an escalation of this conflict and was Mao's personal attempt to rectify the discord within the party. As an authoritative account put it, "the movement was largely the result of the decision of a single man, Mao Zedong." ${ }^{9}$ According to this view, the Red Guard movement that emerged in the first stage of the Cultural Revolution was called into being by Mao and was his shock troops to unsettle his hitherto lieutenants. Joel Andreas, for example, argued that Mao "went outside the party organization to directly mobilize students" in order to attack the party officialdom. ${ }^{10}$ Thus, this account assumes that the starting condition of elite conflict is sufficient to explain the cause of the Cultural Revolution.

Such an assumption is in alignment with the structuralist approach in the social movement scholarship that emerged in the 1970s. ${ }^{11}$ Yet, it takes a narrower interpretation of the political opportunity structure, which it reduces to elite division, because it seems to sufficiently explain the resources made available for student mobilization. ${ }^{12}$ As I will explicate below, elite division is a necessary, but insufficient, condition. Students also played an important role in shaping the rise of the Cultural Revolution, as Mao himself acknowledged in the opening vignette of this article. Moreover, the existing account has emphasized elite division at the expense of other structural affordances at play, especially symbolic structures and cultural schemas, which, as William Sewell Jr. has pointed out, are part and parcel of eventful social transformations. ${ }^{13}$ A richer conception of structures can shed light on the dynamics of becoming that the current account has left out.

As Walder's quotation above indicates, because most social scientists take for granted the elite-conflict account of the rise of the Cultural Revolution, they regard this question as uninteresting and shift their attention to what came after the movement came into being, particularly its factionalism.

\section{THE DYNAMICS OF FACTIONALISM}

While factionalism is a common phenomenon in many social movements, what draws Cultural Revolution scholars' attention is the particular paradox that, while

9. Harry Harding, "The Chinese State in Crisis," in The Cambridge History of China, vol. 15, ed. Roderick MacFarquhar and John K. Fairbank (Cambridge: Cambridge University Press, 1991), 107.

10. Andreas, "Structure of Charismatic Mobilization," 442. As I show below, both Walder's and Andreas's analyses often bear out more complexity than their theoretical models. My critique here is meant to identify analytical inadequacies in order to draw attention to unaddressed questions.

11. Jeff Goodwin and James M. Jasper, Rethinking Social Movements: Structure, Meaning, and Emotion (Lanham, MD: Rowman \& Littlefield, 2004).

12. For more expanded conceptions of political opportunity structure, see David S. Meyer, "Protest and Political Opportunities," Annual Review of Sociology 30 (August 2004): 125-45.

13. William H. Sewell Jr, "Theory of Structure." 
pledging common loyalty to Mao, students (as well as workers and cadres who later joined the movement) were divided into opposing factions and fought each other relentlessly, even defying Mao's call for unity. ${ }^{14}$ Eventually, frustrated with its factionalism, Mao had to send in the military to neutralize the movement. There must have been real motivations beyond the students' professed ideology that drove their actions and generated this "failure of charisma" on the part of Mao. ${ }^{15}$ For this, scholars have predominantly looked for instrumental interest calculations such as career opportunity and political security. There have been two theoretical presuppositions along this line: the older "social interpretation" and the newer "political interpretation."

The social interpretation identifies a strong correlation between an individual's social background and his/her factional allegiance: students who had privileged class origins or ties to the party authority in the status quo ante tended to join conservative factions; those who were disadvantaged joined radical factions. ${ }^{16}$ The point is clear: concern for educational and career prospect was the real motivation for individual actors, whereas ideological pronouncement was simply its justification and rationalization. An upshot of this interpretation is that Red Guard factionalism mirrored the fracturing of elites; two groups of competing elites tried to influence their favored factions through political sponsorship and patronage. ${ }^{17}$

The newer "political interpretation," advanced by Andrew Walder, challenges the social reductionism of the social interpretation and professes to take seriously the political process of factional formation. ${ }^{18}$ It argues that initially the opposing factions were actually composed of students with equally impeccable backgrounds, whose factional choices were rather stochastic due to the contradictory signals sent by two conflicting groups of political elites-the conservative-oriented party hierarchy

14. For factionalism in other social movements, see Christopher K. Ansell, Schism and Solidarity in Social Movements: The Politics of Labor in the French Third Republic, vol. 20 (Cambridge University Press, 2001).

15. Shaoguang Wang, Failure of Charisma: The Cultural Revolution in Wuhan (New York: Oxford University Press, 1995).

16. The most articulate among them are Anita Chan, Stanley Rosen, and Jonathan Unger, "Students and Class Warfare: The Social Roots of the Red Guard Conflict in Guangzhou (Canton)," China Quarterly 83 (1980): 397-446; Hong Yung Lee, The Politics of the Chinese Cultural Revolution: A Case Study (Berkeley: University of California Press, 1980). For a more nuanced social interpretation, see Joel Andreas, "Battling over Political and Cultural Power during the Chinese Cultural Revolution," Theory and Society 31, no. 4 (August 1, 2002): 463-519, and Rise of the Red Engineers: The Cultural Revolution and the Origins of China's New Class (Stanford, CA: Stanford University Press, 2009).

17. See Andrew G. Walder, "Cultural Revolution Radicalism: Variations on a Stalinist Theme," in New Perspectives on the Cultural Revolution, ed. William Joseph, Christine Wong, and David Zweig (Cambridge, MA: Harvard University Press, 1991), 41-61.

18. Andrew G. Walder, "Beijing Red Guard Factionalism: Social Interpretations Reconsidered," Journal of Asian Studies 61, no. 2 (2002): 437-71, "Ambiguity and Choice in Political Movements," and Fractured Rebellion: The Beijing Red Guard Movement (Cambridge, MA: Harvard University Press, 2009). 
and the radical Central Cultural Revolution Group blessed by Mao. Only after August 1966, it contends, did factionalism take on social signification as the two factions legitimated their initial factional choices along sociopolitical lines and attracted followers accordingly in order to fill the power vacuum left by the collapse of party hierarchies. While correcting the social interpretation by showing that in highly uncertain and ambiguous situations like the beginning of the Cultural Revolution the direct link between material interests and action is broken, the political interpretation nevertheless retains the social interpretation's assumption of instrumental rationality: in fact, it mainly adds to it political calculations of reading elite signals and following the correct line, since standing in the wrong camp could be lethal in a politically punitive context. In this interpretation, the language and content of political articulation is again relegated as epiphenomenal to instrumental calculations. ${ }^{19}$

\section{THE MISSING LINKS}

Thus, what's remarkable about the current literature is that it makes the structural conditional theory of elite conflict seemingly compatible with the instrumentally rational conception of individual factional choice. Thus, political elites widened their conflict by mobilizing mass support and competed to define the situation, in which students made their factional choices based on their instrumental calculations, whether these calculations were social or political.

While this characterization enhances the understanding of some aspects of the Cultural Revolution, it disregards the role of interpretation in the event and suppresses the question of how and why the Cultural Revolution turned out the way it did. Addressing this question would help to draw the links between elite conflict and student mobilization that the existing literature lacks.

The conventional narrative that Mao launched the Cultural Revolution in order to call on the masses to rectify the problems within the party's officialdom is built, first, upon selective reading of Mao's critical enunciations about the party officialdom before the Cultural Revolution and, second, upon the retrospective account that Mao and his associates constructed after it was already well into its course.

First, there indeed existed tensions between Mao and the party bureaucracy: he had previously initiated campaigns to rectify the party bureaucracy, and before the Cultural Revolution, Mao made harsh comments about it on a few occasions. During the polemics of the Sino-Soviet split (1963-64), Mao explicitly attributed Soviet

19. Joel Andreas, review of Fractured Rebellion: The Beijing Red Guard Movement, by Andrew G. Walder, American Journal of Sociology 116, no. 3 (November 2010): 1026-29. 
revisionism to the succession of Stalin by party bureaucrats, whom he believed had become a privileged stratum and betrayed the communist cause. ${ }^{20}$ He made it clear that he would by all means prevent the same from happening in China. In January 1965, during the Four Cleans campaign to rectify the party, he targeted the "capitalist roaders" within the party and even spoke of "a class of bureaucrats . . who are sucking the blood of the workers." ${ }^{21}$ On another occasion, he expressed his distrust of the work teams in charge of the campaign on the ground, for they lacked local knowledge or became bureaucrats "obstructing the campaign." ${ }^{22}$

Second, since early 1967, Mao and his associates articulated the thesis of twoline struggle: a long-standing struggle between two party lines between Mao and revisionists within the party, which began in the early 1960s and culminated in the epic battle of the Cultural Revolution. According to Mao, the Cultural Revolution was "a form, a method, to arouse the broad masses to expose our dark aspect openly, in an all-round way and from below," a comment made in February 1967 but often taken as Mao's grand vision before the fact. ${ }^{23}$ This thesis was reinforced and naturalized by Red Guards' ex post facto justification claims that they were following Mao's instruction, even though such claims were not borne out by actual organizational dynamics. The post-Mao official verdict, although inverting the moral judgment of the Maoist narrative, retained its explanatory framework: Mao, it claims, was misguided by a handful of power-hungry leftists and erroneously called on the masses to attack innocent party officials.

Drawing a linear connection between these before/after statements, the conventional narrative depicts the inevitable clash between a charismatic leader and his administrative staff, thus reading the event in light of Weber's theory of the routinization of charisma, Robert Michels's "iron law of oligarchy," and the neo-Marxist "new class" theory. ${ }^{24}$ Yet, this linear connection suffers from some crucial missing

20. MacFarquhar, Origins of the Cultural Revolution, 363.

21. Zhonggong zhongyang wenxian yanjiushi [Central Archives Research Office], ed., Jianguo yilai zhongyao wenxian xuanbian [Compilations of important documents since the founding of the Republic], vol. 20 (Beijing: Zhongyang wenxian chubanshe, 1992), 21.

22. Mao Zedong, Mao Zedong sixiang wansui [Long live Mao Zedong's thought, 1961-1968] (n.p., 1969), $227,221$.

23. Ibid., 288. It was this expression that Lin Biao, in his report to the Ninth National Congress of the $\mathrm{CCP}$, selected to prove Mao's great vision. Lin Biao, "The Report to the Ninth National Congress of the Communist Party of China," in Mao Tse-tung and Lin Piao, ed. K. Fan (Garden City, NJ: Anchor Books, 1972), 419-67, esp. 431-32.

24. Max Weber, Economy and Society: An Outline of Interpretive Sociology (Berkeley: University of California, 1978), 246, 1121; Robert Michels, Political Parties: A Sociological Study of the Oligarchical Tendencies of Modern Democracy (Glencoe, IL: Free Press, 1949); Gyorgy Konrad and Ivan Szelenyi, The Intellectuals on the Road to Class Power (New York: Harcourt Brace Jovanovich, 1979). A typical example of this interpretation is Joel Andreas's "Structure of Charismatic Mobilization," even though his analysis of organizational dynamics is 
links and does not match with the unfolding of events in between. Indeed, the existing literature has unearthed ample evidence to demonstrate Mao's strategizing to purge party officials whom he singled out for accommodating the ideological assault in the debate over Hai Rui Dismissed from the Office, a historical play that Mao considered a satire of himself. ${ }^{25}$ Yet, what is missing is the evidence to draw a clear connection between elite conflict and mass mobilization that would demonstrate how Mao directly mobilized students in order to unsettle the party establishment. A thorough search of historical records, ranging from party documents through Mao's official chronological records (Mao Zedong Nianpu) to People's Daily, yields no clear evidence that Mao had a master plan to orchestrate that outcome before the event, not to mention to carry it out through concrete organizing mechanisms. The existing literature is fully aware of these missing links yet tends to resort to mysticism due to its attachment to the elite-conflict theory. For example, in Mao's Last Revolution, MacFarquhar and Schoenhals acknowledge, "the process by which Mao translated high-level political intrigue into mass mobilization remains one of the many obscure issues of the Cultural Revolution." ${ }^{26}$ The main seemingly credible evidence-the big-character poster incident at Beijing University encouraged by the wife of Mao's close associate Kang Sheng-was essentially intrabureaucratic conflict: all seven individuals involved were party cadres deeply implicated in the university's bureaucratic infighting since $1964 .^{27}$

Moreover, a close examination of the initial phase of the Red Guard movement indicates its relatively autonomous logic: (1) students were already well disposed toward radical mobilization on the eve of the Cultural Revolution; (2) instead of Mao going "outside the party organization to directly mobilize students" to attack the party officialdom, ${ }^{28}$ students were actually initially mobilized by the party bureaucracy to attack those party officials and intellectuals whom Mao had singled out for the purge; (3) their conflict with the party establishment instead emerged

actually a departure from the elite-centered interpretation of charisma. For critiques of the elite-centered interpretation of charisma theory, see Pierre Bourdieu, "Legitimation and Structured Interests in Weber's Sociology of Religion," in Max Weber, Rationality and Modernity, ed. Scott Lash and Sam Whimster (London: Allen \& Unwin, 1987), 119-36; Pierre Bourdieu and Jean Claude Passeron, Reproduction in Education, Society and Culture (London: Sage, 1990), 25-26.

25. Roderick MacFarquhar and Michael Schoenhals, Mao's Last Revolution (Cambridge University Press, 2006), 15.

26. Ibid., 54.

27. Chen Tushou, "Feng Ding: Dapipan kunju zhong de qizi" [Feng Ding: A pawn in the game of great criticisms], in Guguo renmin yousuosi [Thinkers from the Old Regime] (Beijing: Sanlian, 2013), 212; Andrew G. Walder, "Factional Conflict at Beijing University, 1966-1968," China Quarterly 188 (December 2006): 1025-26.

28. Andreas, "Structure of Charismatic Mobilization," 442. 
and expanded in the process as they clashed over how to define the Cultural Revolution. These factual incongruences indicate that the rise of the Cultural Revolution cannot be reduced to elite conflict, as the "two-line struggle" thesis posits.

As Lowell Dittmer insightfully suggested, the two-line struggle thesis was teleological: a retrospective construction crafted by the Maoists, it in effect papers over the interactive contingency in the Cultural Revolution's emergence. Taking it for granted is analytically guilty of confusing cause with effect. Although there existed a functional division since 1962 between Mao and his lieutenants who exhibited different policy styles, it did not become a power cleavage until August 1966, when Mao recalled work teams, which he had earlier authorized Liu Shaoqi to dispatch to the schools. It was only because of the work teams' heavy-handed handling of students that Mao was able to frame the work teams and the Central Party leadership in the image of Soviet "revisionists." Hence, "in the absence of mass mobilization no line struggle could have conceivably developed." ${ }^{29}$ In other words, the tension between Mao and his lieutenants was necessary but insufficient for explaining the rise of the Cultural Revolution.

This means that student mobilization should not only be conceptualized as a subsequent progress triggered by the antecedent elite conflict, which defined the political context in which students made their choices. Rather, student mobilization also helped to redefine the terms of elite conflict. The emergence and becoming of the Cultural Revolution was a conjuncture of these two causal chains, as a result of the struggle among various actors over the definition of the unfolding situation.

The perspective of dialogic struggle helps us to capture these dynamics. Developing Bakhtin's dialogicist theory, Marc Steinberg argued that "struggle over interpretation" should be placed at the center of understanding collective action. ${ }^{30}$ Because of the multivocality of ideological formations, actors sometimes are able to appropriate elements of hegemonic discourse and in the process refine collective issues. This perspective implies rethinking both individual agency and structural affordances at play: the former can be more than instrumental calculation and the latter can be more than elite conflict.

\section{A GENCY}

The existing literature conceptualizes individual students as instrumental calculators in a context defined by political elites. This is straightforward for the "social in-

29. Lowell Dittmer, "Line Struggle' in Theory and Practice: The Origins of the Cultural Revolution Reconsidered," China Quarterly 72 (1977): 702.

30. Steinberg, "The Talk and Back Talk of Collective Action," 745. 
terpretation" of factionalism. While the political interpretation has emphasized situational ambiguity in this emergent process, it conceptualizes it only as a context in which students of identical background made stochastic factional choices, which then became path-dependent. This way, it ignores the struggle over interpretation in the emergence and unraveling of this situational ambiguity by overlooking, first, that students were engaging in sense making, which was contingent but not purely by chance; ${ }^{31}$ second, that the situation was ambiguous not only to students but also to political elites, ${ }^{32}$ and, most importantly, that students' actions also helped shape the definition of the situation and create interpretative problems for political elites. A brief examination of the June 18 incident at Beijing University-a pivotal event in the early Cultural Revolution-helps to clarify.

Two weeks after the party center, with Mao's consent, sent a work team of 208 members strong to take over control of Bejing University on June 1, 1966, the university was again in turmoil, as students demanded struggle sessions against ousted university leaders, whom the work team had disgraced and put in custody. On June 18, militant students went against the work team's rules, dragged more than sixty former university cadres out of custody, and organized struggle sessions against them. Students styled these struggle sessions after Mao's 1927 “Report on an Investigation of the Peasant Movement in Hunan," in which young Mao celebrated tactics and rituals of peasant jacqueries against landlords in his home province. ${ }^{33}$ Yet, these practices contradicted the routine political repertoires in the postrevolutionary era (1949-66). Hence, both the work team and the Central Cultural Revolution Group actually declared the incident counterrevolutionary. ${ }^{34}$ The party central administration then set it up as a negative example nationwide.

Yet, the incident immediately polarized students. Some students defended these practices by quoting Mao's 1927 report that "revolution is not a dinner party"; others condemned them by arguing that "Yan'an [socialist China] is not Xi'an [old regime

31. For the distinction between chance and other types of contingency, see Ivan Ermakoff, "The Structure of Contingency," American Journal of Sociology 121, no. 1 (2015): 64-125.

32. Li Xuefeng's memoir best captures the state of confusion among political elites. Li Xuefeng, "Huiyi 'wenhua da geming' chuqi de 'wushi tian luxian cuowu': Cong '6.18' shijian dao '7.29' dahui" [Recalling the "Fifty-Day Erroneous Line" of the early "Cultural Revolution": From the June 18th incident to the July 29th mass meeting], Zhonggong dangshi yanjiu 1998 (4): 1-11.

33. Victor Nee and Don Layman, The Cultural Revolution at Peking University (New York: Monthly Review Press, 1969), 62-63; Tang Li, "Wo de beida wenge jiyi" [My memory of the Cultural Revolution at Beijing University], Minjian lishi [Folk history], 2012, pt. 2, accessed on June 5, 2015, http://mjlsh.usc.cuhk.edu .hk/book.aspx? cid $=2 \delta$ tid $=879$ \&pid $=4087$.

34. Zhang Chengxian, "Wenhua dageming chuqi de beida gongzuozu" [Beijing University work team during the early Cultural Revolution], Zhonggong dangshi ziliao 70 (1999): 31; Wang Li, Wang Li fansi lu [Wang Li's recollections and reflections], vol. 2 (Hong Kong: Beixing chubanshe, 2001), 607-8. 
China]" and that old revolutionary repertoires no longer apply. ${ }^{35}$ Such division escalated when wall posters appeared on July 12, in which some students attacked the work team for "suppressing mass movement" in the June 18 incident. ${ }^{36}$ After Mao returned to Beijing on July 18 and expressed his disapproval of the work teams to his close associates in top party echelons and the Central Cultural Revolution Group, the latter reversed its position and began accusing the Beijing University work team of mishandling the "revolutionary" incident, leaving the work team bewildered. This drove a deeper wedge among students over whether the work team was guilty of suppressing mass movement. On the nights of July 25 and 26, thousands from the university and nearby schools attended two "big debate" meetings on campus, where elite division as well as student factionalism went public. ${ }^{37}$

Therefore, the process of initial factional formation in this most pivotal case was rather contrary to the political interpretation, which would predict that the conservative work team and radical Central Cultural Revolution Group would send contradictory signals to students, who would then scramble to stand on the right side. Instead, students mobilized distinct cultural repertoires and performed actions that contradicted the party's institutionalized scripts and contributed significantly to the confusion and chaos. Initial factional formation was largely based on the struggle over interpreting this contingent event and the party bureaucracy's response to it. And this struggle over interpretation in turn confounded political elites. As Deng Xiaoping put it at this juncture, "we the old revolutionaries have run into new problems." 38 While students were imitating the practices of past revolutionaries, party officials at the time, including many of Mao's close followers in the Central Cultural Revolution Group, considered these practices disruptive of the socialist social order. $^{39}$

\footnotetext{
35. Li Yangyang, "Yichang jingxin cehua daoyan de xi: 1966nian 7yue 26ri de bianlun hui" [A well orchestrated episode: The debate meeting on July 26, 1966], China News Digest 909 (2013), accessed July 15, 2015, http://www.cnd.org/CR/ZK13/cr741.gb.html\#01; Ma Shengxiang, "Beida wenge chuqi jianwenlu" [A recollection of the early Cultural Revolution at Beijing University]," Wenshi Jinghua (2006 [7]): 53. For similar scenarios elsewhere, see Xu Youyu, Xingxingsese de zaofan: Hongweibing jingshen sushi de xingcheng yu yanbian [Varieties of rebellion: The formation and evolution of the Red Guard ethos] (Hong Kong: CUHK Press, 1999), 36-37; Ken Ling, Miriam London, and Ta-ling Lee, Red Guard: From Schoolboy to "Little General" in Mao's China (London: Macdonald, 1972), 19.

36. Zhang Chengxian, "Wenhua dageming chuqi de beida gongzuozu," 33.

37. Ibid., 39; Li Xuefeng, "Huiyi 'wenhua da geming' chuqi de 'wushi tian luxian cuowu': Cong '6.18' shijian dao '7.29' dahui," 7-9.

38. Walder, Fractured Rebellion, 90.

39. Zhang Chengxian, "Wenhua dageming chuqi de beida gongzuozu," 31; Wang Li, Wang Li fansi lu, $2: 607$.
} 


\section{IDEOLOGICAL CONTRADICTIONS AS SOURCE OF CONTENTION}

The fact that students invoked past revolutionary repertoires-which were elements of the state ideology-that contradicted established policies suggests that a broader conception of political opportunity structures should include cultural resources that afforded the construction of political contention in this case. ${ }^{40}$ More specifically, it brings to light the importance of ideological contradictions in generating social change. While Marxism has been the most notable in advancing the notion of inner structural contradictions, William Sewell Jr. has broadened it to encompass ideological tensions. Extending the notion-expounded in French structuralism and Giddens's idea of the duality of social structures-that ideology is deeply structural and hence constitutive of social order, he argued that ideological dynamics are also part and parcel of social change. He showed that the rise of the French Revolution was largely driven by internal ideological contradictions within the Old Regime in France, such as that between corporate privileges and the impersonal centralizing monarchical state. ${ }^{41}$ In a series of articles, he further developed this approach to social change, which he argued should be considered as disarticulations of the old structures and rearticulations of the new, effectuated through momentous events, in which actors' interpretive struggle over contingent yet disruptive happenings, such as the storming of the Bastile, is constitutive of the structural transformations. ${ }^{42}$

Here, the terminologies of articulation, disarticulation, and rearticulation convey two interrelated senses: social structure is "an unevenly articulated network" of schemas, resources, and power relations; ${ }^{43}$ its stability and change necessarily depend on social agents' dialogic struggle, which either repair the unevenness of that network and weave social structure together (articulation and rearticulation) or fail to do so and generate new social structure (disarticulation and rearticulation). The presence of strong ideological contradictions, when embodied by a carrier group, often coincide with shifting resource distribution and unsettling power relations and lead to major social transformations like the French Revolution.

This approach helps us to comprehend the prevalent sense of ideological contradictions on the eve of the Cultural Revolution that former Red Guards often recall, as well as the causal role of these contradictions in the becoming of the Cultural

40. Meyer, "Protest and Political Opportunities."

41. Sewell, "Ideologies and Social Revolutions."

42. Sewell, "Theory of Structure," and "Historical Events as Transformations of Structures." For a thoughtful discussion of structural contradictions as methodology, see Alex Callinicos, The Resources of Critique (Cambridge: Polity, 2006), 182-216.

43. Sewell, "Historical Events as Transformations of Structures," 842. 
Revolution. ${ }^{44}$ As will be shown below, these contradictions resulted from the partystate's attempt to synthesize its ideological justification with a routinizing socialist order after the Anti-Rightist campaign (1957) and the disastrous Great Leap Forward (1958-60). Yet, they deeply shaped the group ethos of militant students, which predisposed them to spontaneous and disruptive styles of mobilization that ran counter to what Joel Andreas calls the party's bureaucratic methods of mobilization. $^{45}$

\section{DIALOGIC STRUGGLE AS THE MISSING LINK BETWEEN ELITE}

CONFLICT AND MASS MOBILIZATION

Advancing notions of dialogic struggle and structural disarticulations enables us to grasp the coming-into-being of the Cultural Revolution as a structured yet contingent process. It is more structured than the conventional narrative, because, in addition to elite division, it also involved other structurally afforded sources such as ideological factors. It is also more contingent than the conventional teleological narrative, because it hinged on the conjuncture of two largely separate causal chainselite conflict and the formation of a student militant ethos-whose intersection induced contingent interpretive and significative interactions among various actors. ${ }^{46}$

Hence, instead of Mao orchestrating students' conflict with the party bureaucracy beforehand, he in fact intervened after militant students were clashing with it, when he interpreted the latter's heavy-handed treatment of students in light of Soviet "revisionism." What is particularly noteworthy is the changing meaning of "cultural revolution" resulting from these contingent interactions. Mao indeed began to push for a "cultural revolution" as early as 1964 and stepped up this initiative in late 1965 through the critique of the Hai Rui play. Yet it is mainly conceived as an ideological offense against "bourgeois" intellectuals, which escalated in AprilMay 1966 into a purge of officials who he believed had been ideologically contaminated. The party bureaucracy followed by mobilizing students for loyalty fortification that typically accompanied political purges in Stalinist polities. So far, there was little disagreement between Mao, party officials, and students regarding the goal of "cultural revolution" as an ideological purge.

Yet, at this juncture, frictions developed between party officials and students regarding the means and meaning of carrying out this "cultural revolution": while

44. Carma Hinton's documentary film Morning Sun has most visibly highlighted it.

45. Andreas, "Structure of Charismatic Mobilization."

46. For the relationship between contingency and conjunctural causation, see James Mahoney, "Path Dependence in Historical Sociology," Theory and Society 29, no. 4 (2000): 527. See also Ermakoff, "The Structure of Contingency." 
party officials interpreted it as a bureaucratically controlled purge after the fashion of the Anti-Rightist campaign of 1957, students were informed by spontaneous styles of mobilization that resulted from the disarticulations of ideological contradictions they experienced. ${ }^{47}$ During their escalating conflict with bureaucratic control, students rearticulated the meaning of "cultural revolution" as "rebellion is justified." It is in this context that Mao decisively pivoted toward student rebellion and embraced these new constituents, cementing what Bu Dahua, leader of the first Red Guard organization, calls the "telepathy" between Mao and Red Guards at that historical moment. ${ }^{48}$

Therefore, the conjuncture of the intra-elite purge and the formation of a student revolutionary ethos created an emergent process in which tension between the party bureaucracy and students arose and was rearticulated into how to define "cultural revolution." Mao initiated a purge, which triggered the causal conjuncture yet came to embrace students' interpretation in light of their growing conflict with party officials. Because the existing causal explanation has already focused on the first causal chain-elite conflict- the rest of this article focuses on two agendas: first, to introduce the second causal chain, the formation of a revolutionary ethos, and to show how on the eve of the Cultural Revolution students were well disposed to interpret "cultural revolution" radically differently from party officials; second, to trace the interactive dynamics emerging from the conjuncture of the two causal chains, through which the Cultural Revolution came to be what it is known for: "rebellion is justified."

\section{INTERMEDIATE CONSIDERATIONS}

My analysis of the emergent dynamic of the Cultural Revolution is divided into two parts. Section IV accomplishes my first agenda by examining the ethos of students on the eve of the Cultural Revolution. I show that students were experiencing contradictions between their longing for the revolutionary past and the reality of the routinized present, contradictions that were induced by Mao and the party's relentless ideological campaigns to reassert their authority and control after consecutive legitimation crises in the late 1950s and early 1960s. Due to these deeply felt con-

47. This brings up the observation, complementing the current conception of spontaneity in collective action, that ideological contradictions may induce spontaneous collective action even in highly controlled and regimented environments. See David A. Snow and Dana M. Moss, "Protest on the Fly: Toward a Theory of Spontaneity in the Dynamics of Protest and Social Movements," American Sociological Review 79, no. 6 (2014): 1122-43.

48. Bu Dahua, "Hongweibing zhiqi" [Red Guards' flag], in Hongweibing milu [The secret records of the Red Guards], ed. Yu Hui (Beijing: Tuanjie chubanshe, 1993), 9. 
tradictions, party officials took the Cultural Revolution as another typical top-down loyalty fortification campaign and called on students to support Mao's purge in early May 1966. But students approached the Cultural Revolution differently, in effect reordering the temporal landscape and turning the "cultural revolution" into their longdesired chance to become revolutionaries. ${ }^{49}$

Section V executes my second agenda. It examines the emergent dynamics whereby students, empowered by these dispositions, came to clash with the party bureaucracy (which initially called them into action) and to articulate the notion of "rebellion is justified," which Mao then endorsed. By examining the case of Qinghua High School Red Guards—-the first Red Guard organization—Section V demonstrates that the notion that Cultural Revolution activism was about justifying rebellion was not Mao's original program, as the conventional narrative posits, but the outcome of a contingent interactive process in which students played a vital role.

In Section IV, I mainly draw on primary sources concerning pre-Cultural Revolution party policies and Red Guard activists' self-accounts that I collected from a rich body of memoirs, autobiographies, and interview materials. These sources helped me to reconstruct the general ethos of students before they encountered the Cultural Revolution. Using retrospective self-accounts has methodological limitations in that they might bear the imprint of subsequent events and ideological changes, which might have influenced how individuals interpret their experience during the period under study. However, this limitation is significantly offset by the fact that the pattern I identify is quite consistent in the self-accounts of Red Guards who came from different family backgrounds (cadres, intellectuals, professionals, workers, etc.); belonged to various factions ("old Red Guards," "rebels," "conservatives"); adopted different ideological orientations in the post-Mao period (neoleftists and liberals); and currently live on different continents (China and in diaspora, especially in North America).

These accounts are by no means representative of the whole population of former Red Guards. Rather, they are skewed toward the better-known participants. Most of these self-accounts come from highly articulate individuals: historians, philosophers, social scientists, literary scholars, filmmakers, writers, and so forth. Their accounts have a degree of reflexivity similar to what Thomas Merton called "socio-

49. For how individual agency is manifested in experiences of temporal landscape, see Mustafa Emirbayer and Ann Mische, "What Is Agency?," American Journal of Sociology 103, no. 4 (1998): 962-1023; Iddo Tavory and Nina Eliasoph, "Coordinating Futures: Toward a Theory of Anticipation," American Journal of Sociology 118, no. 4 (2013): 908-42. 
logical autobiography" and are particularly useful to sensitize my analysis to the historical dynamics involved. ${ }^{50}$

Section V relies on a collection of wall posters and other primary sources related to the Qinghua High School Red Guards as well as self-accounts of individuals who directly witnessed or were involved in its formation. These include party officials from the school's work team and higher-level officials and students who were members of the organization as well as those who were opposed to or victimized by it. These diverse angles provide a comprehensive view of the dynamics leading up to the confrontation between students and the party bureaucracy, before Mao weighed in to support students. By detailing how the students' revolutionary ethos documented in Section IV intersected with the elite division in the emergence of Cultural Revolution activism, Section V strengthens my focus on dialogic struggle. I then discuss how this approach helps to contextualize Mao's ideas and actions.

\section{THE PARADOXICAL GENESIS OF REVOLUTIONARY ETHOS}

Group ethos plays an important role in social movement mobilization. ${ }^{51}$ To understand the students' general ethos when the party bureaucracy mobilized them to participate in the Cultural Revolution in early May 1966, it is necessary to place it in the context of the series of bureaucratically orchestrated mobilizations and propaganda campaigns that they had already been subjected to since the early 1960s. These bureaucratic mobilizations did not generate straightforward authoritarian indoctrination but rather internal contradictions that shaped how students approached the Cultural Revolution. ${ }^{52}$

After the Anti-Rightist campaign (1957), which purged over half a million individuals, and the Great Leap Forward (1958-60), which resulted in one of the worst famines in world history, the party-state stepped up political educational campaigns targeted at the youth. The official rationale was based on a speech Mao delivered in 1957:

Because of their lack of experience in political and social life, quite a number of young people can't make a proper comparison between the old and new

50. Thomas Merton, "Some Thoughts on the Concept of Sociological Autobiography," in Sociological Lives, ed. Martha White Riley (Newbury Park, CA: Sage, 1988), 17-21.

51. Xiaohong $\mathrm{Xu}$, "Belonging Before Believing Group Ethos and Bloc Recruitment in the Making of Chinese Communism," American Sociological Review 78, no. 5 (2013): 773-96.

52. Anita Chan used Adorno's notion of "authoritarian personality" to analyze the role of ideology in Red Guards. Anita Chan, Children of Mao: Personality Development and Political Activism in the Red Guard Generation (London: Macmillan, 1985). Although Andreas emphasizes the tension between bureaucratic and charismatic mobilization, he nevertheless believes that it was Mao alone who unleashed the students' charismatic mobilization. See Andreas, "Structure of Charismatic Mobilization." 
China; it is not easy for them to thoroughly comprehend what hardships the people of our country went through in the struggle to free themselves from the oppression by the imperialists and Kuomintang reactionaries, or what a long period of painstaking work is needed before a happy socialist society can be established. That is why political educational work should be kept going among the masses in an interesting and effective way. ${ }^{53}$

The early 1960s saw relentless campaigns to reassert Mao's and the party's authority. These campaigns generally took two forms. On the one hand, they stressed the people's sufferings in the old China and glorified the revolutionary struggles through which Mao and the party heroically led the people to found a new socialist society. ${ }^{54}$ On the other, the party promoted a series of ordinary Stakhanovite "socialist builders" for students to emulate in their daily life. ${ }^{55}$ Among them, the most prominent was Lei Feng, a solider whom Mao called on the Chinese youth to emulate after his death in 1962. Lei was celebrated for his utmost loyalty to the party and selfless devotion to helping others and building socialism. His posthumous diaries, in which he prided himself for being a "never-rusting screw" in the "socialist machinery" and a forever "docile tool" of the party, were widely distributed. ${ }^{56}$ An engineer and former Red Guard, Zhai Zhenhua, recalls that every student in her school had a copy of Excerpts from Lei Feng's Diary and was able to recite his famous quotations. ${ }^{57}$ Students were instructed to follow his example to do good deeds and to imitate his writing and thinking.

While being effectively carried out, these campaigns generated enormous tensions as perceived by students. As historian and former Red Guard Ye Weili put it, "our education was filled with contradictions. On the one hand we were told to be screws and obedient tools of the party and the nation. On the other hand there was so much talk about revolutionary heroism." ${ }^{58}$ The contradictions took a temporal form, between the past and the present. On the one hand, students longed for the glamor of the revolutionary past. As philosopher Xu Youyu put it, "We thought the

53. Mao Tse-tung, On the Correct Handling of Contradictions among the People (Peking: Foreign Languages Press, 1957), 60

54. Ibid.

55. Mary Sheridan, "The Emulation of Heroes." China Quarterly 33 (1968): 47-72. For broader historical context and post-Mao legacy, see Børge Bakken, The Exemplary Society: Human Improvement, Social Control, and the Dangers of Modernity in China (Oxford: Oxford University Press, 2000).

56. Lei Feng, Lei Feng riji [Diaries of Lei Feng] (1963; Beijing: Jiefangjun wenyi, 1964), 77, 12.

57. Zhai Zhenhua, Red Flower of China (New York: Soho Press, 1992), 41.

58. Ye Weili and Ma Xiaodong, Growing Up in the People's Republic: Conversations between Two Daughters of China's Revolution (New York: Palgrave Macmillan, 2005), 89-90. 
glamorous moment of life was not in the lab, on the award-granting podium, but in the torrent of great revolutions. .. . But, our classroom study in more than ten years seemed so far away from this kind of idealist world. I often thought that our generation was so miserable: Why was I not born in the age of great revolutions? Why have I missed the May Fourth demonstration, the Long March, the Anti-Japanese War, etc.?"59 On the other, they were confronted with the routinized socialist present. As sociologist Ma Xiaodong recalled, "Paul and Gadfly, along with Gao Shan and the soldiers in the Red Detachment of Women were all people who lived in exciting war times. I loved books and films on war. I often thought that it was a shame I was not born in wartime. I missed the opportunity to become a hero . . I just longed to live a thrilling life like the heroes in books and on screen. What I couldn't bear was being mundane." ${ }^{60}$ To make up their lost opportunity to participate in a real revolution, some resorted to playing "revolutionary games." Shi Tiesheng, an acclaimed writer of the Red Guard generation, remembered that whenever he and his friends learned about revolutionary stories, they would role-play the stories. Sometimes they had trouble deciding who would play the enemies because it was always preferable to play revolutionary heroes. ${ }^{61}$

While Xu Youyu, Ma Xiaodong, and Shi Tiesheng had spent their revolutionary fantasy in private thought and games, others began to challenge the kind of exemplary education that they were subjected to. Many students openly declared that they identified themselves less with "docile" and conformist models than with past revolutionary heroes. They disdained to spend their wits and time on those petty "good deeds" that were promoted in the "Learn-from-Lei Feng" campaign and could help individuals get ahead in the system. However, the educational authority denounced their argument and reasserted that only by serving the Party as "neverrusting screws" could they contribute most to the socialist cause. ${ }^{62}$

The party policy deemed revolutionary history to be useful to foster students' loyalty yet unsuitable for their emulation due to different historical circumstances. As a pamphlet by the Communist Youth League instructed, "Many of our young comrades admire heroic figures and are determined to learn from them. This is understandable. But because the concrete environment and social condition in which heroes lived differs from our condition, we should not emulate them on the sur-

59. Xu Youyu, "Wo zai 1966" [My life in 1966], in 1966: Women nayidai de huiyi [1966: Memories of our generation ], ed. Xu Youyu (Beijing: Zhongguo wenlian Publishing Company, 1998), 20.

60. Ye and Ma, Growing Up in the People's Republic, 89.

61. Shi Tiesheng, Jiyi yu yinxiang [Memories and impressions] (Beijing: Beijing chubanshe, 2004), 81.

62. Chan, Rosen, and Unger, "Students and Class Warfare," 411-12. Also, see Ye and Ma, Growing Up in the People's Republic, 60-61. 
face, but ought to learn from them in essence, that is, learn their revolutionary spirit, their high responsibility for the revolutionary cause and their lofty altruistic character. . . . If we just emulate the deeds of heroes, then we would meet many limits, and moreover, would not be able to draw more spiritual strength from heroes." 63

Crucial to this temporal demarcation between revolutionary past and socialist present was the dissociation of revolutionary spirit, which was now embodied in socialist builders, from revolutionaries qua actors. Literary scholar and former Red Guard You Xilin captures this perceptively, “From the 1950s on, 'revolutionaries' had become a historical concept and been replaced by 'builders.' Even in years when class struggle was much emphasized, the image that the word 'revolutionary' invoked was not someone who was handcuffed and shouldered the revolutionary cause. A deep impression was that 'revolution' and 'revolutionaries,' on the one hand, were two of the most frequently used words in New China after the victory of revolution, yet, on the other hand, became more and more abstract. However, it was the Cultural Revolution that restored the true meaning of 'revolutionaries.'" 64

Although the educational authority did not tolerate open challenge to its exemplary education, students' imitation of past revolutionary heroes in their daily lives appeared less deviant. Filmmaker Chen Kaige recalls that on the eve of the Cultural Revolution, his high school was full of students imitating the ascetic lifestyle of young Mao Zedong, their greatest hero:

On the campus of my No. 4 High School, there were many students of this kind [imitators of young Mao] walking around. They all kept crew cuts, held books under their arms, and dressed very simply. Even when their clothes were still new, they would put patches on. Some even refused to wear socks in winter. . . Some of them could recite Marx and Lenin passage after passage and cited them for oratory persuasion. During heavy rains, one could always see people running and shouting under the raining sky; when thunders roared, they walked as if unruffled. For every meal, they brought simple food in aluminum containers and discussed earnestly while eating. ${ }^{65}$

63. CYPH [China's Youth Publishing House], ed., Xiang yingxiong xuexi [Learn from heroes] (Beijing: Zhonggong qingnian chubanshe, 1953), 15.

64. You Xilin, "Wenge jingkuang pianduan" [Fragments of my Cultural Revolution experiences], in Xu Youyu, 1966: Women nayidai de huiyi, 5.

65. Chen Kaige, Women dou jingli guo de rizi [The life we all have experienced] (Changsha: Hunan Literature and Arts Publishing House, 1996), 23-24. 
Even in the Learn-from-Lei Feng campaign, revolutionary ethos began to take over the routinized mundaneness. Xu Youyu recalls: “There were two interpretations of Lei Feng spirit. The first one was: be ready to help others, achieve extraordinary contribution in an ordinary post, and be a willing screw of the revolutionary cause. But the closer it approached to the Cultural Revolution, the more prevailing the second interpretation was, that is, "to treat our comrades with the warmth of spring, and to treat our enemies with the cruelty and mercilessness of severe winter."'"66

From the above analysis, it is evident that Mao and the party's efforts to reaffirm their authority in the early 1960s generated internal contradictions. Students found themselves emulating past revolutionary heroes instead of present socialist builders, thus transposing and repurposing the state-promoted exemplary education. ${ }^{67}$ On the other hand, their enactment of revolutionary identification was contained by the official temporal landscape that relegated revolutionary events to the past. When party officials called on students to participate in the "cultural revolution" in early May, which they (and, probably to a lesser degree, Mao) interpreted as another AntiRightist purge, students approached it rather differently: they in effect unravelled the ideological contradictions they were confronted with, just like the kind of structural disarticulation that Sewell has examined with regard to the French Revolution. ${ }^{68}$ Specifically, students engaged in reordering the official temporal orientation in a way that Emirbayer and Mische point out as essential to social agency: they embraced it as their long-lost chance to become revolutionaries. ${ }^{69}$ By imitating past revolutionaries and mobilizing their repertoires (as the aforementioned June 18 incident shows), they brought revolutionary events back to the present. As philosopher $\mathrm{Xu}$ Youyu recollects vividly: "Suddenly, chance and fortune have come to favor us. Under the encirclement and blockage of imperialism and reactionaries from various states and after the Soviet Union has betrayed socialist principles, China has waged a great revolution that will save human destiny. ... The sense of mission is mixed with the sense of happiness. Immense excitement and waves of joy are battering our heart and making me breathless." 70

66. Xu Youyu, "Hongweibing xingwei dongyin de diaocha he fenxi" [An investigation and analysis of the motives of the Red Guards' behavior], in Canjue de chuanglanban [The broken elbowboard: Red Guards in history], ed. Li Hui (Shenzhen: Haitian Publishing House, 1998), 135.

67. Sewell, "Theory of Structure," 17; John F. Padgett and Walter W. Powell, "The Problem of Emergence," in The Emergence of Organizations and Markets (Princeton, NJ: Princeton University Press, 2012), 1-29.

68. Sewell, "Ideologies and Social Revolutions," and "Historical Events as Transformations of Structures."

69. Emirbayer and Mische, "What Is Agency?"; Tavory and Eliasoph, "Coordinating Futures."

70. Xu Youyu, “Wo zai 1966," 20. 
Therefore, it is clear that elite division and purge - the first causal chain that the existing literature has underscored-activated the second causal chain, that is, students' predisposition for militant activism, which was well in force by the eve of the Cultural Revolution. The next section shifts the focus to the conjunctural causation of the two chains by examining the microdynamism of the rise of the first Red Guard organization-the Qinghua High School Red Guards-which was also the first to elucidate the notion of "rebellion is justified."

\section{REBELLION UNBOUND: THE QINGHUA HIGH SCHOOL RED GUARDS}

Founded on May 29, 1966, in the high school attached to Qinghua University, China's leading university of technology, Qinghua High School Red Guards was the first mass organization to emerge in the Cultural Revolution. After its founding, the name "Red Guards" was immediately adopted by students in other schools who organized similar groups. ${ }^{71}$ The name soon spread across the country. Since then, the youth movement in the Cultural Revolution has been known as the Red Guard Movement.

Qinghua High School was one of the most academically competitive high schools in Beijing in the 1960s. With its dual emphasis on active political education and academic performance, it attracted aspiring and bright students from families of middling intellectuals and revolutionary cadres. ${ }^{72}$ This dual emphasis also meant that students here were even more susceptible to the contradictions between revolutionary legitimation and bureaucratic control than elsewhere. I have shown above that students had already developed their predispositions for militant mobilization on the eve of the Cultural Revolution. This was also true in Qinghua High School: already in October 1965, a few students who later made up the core of the Red Guards wrote a wall poster (xiaozibao) entitled "Long Live the Spirit of Rebellion." In it, they claimed that rebellion was "the great motor of history," as there would have been no socialist New Society without revolutionaries' rebellion against the semicolonial and semifeudal Old Society. They championed the same spirit of rebellion against rules and discipline in education and ridiculed the "royalists" who knew

71. Bu Dahua, “Wosuo zhidao de hongweibing” [What I know about the Red Guards], in Huiyi yu fansi hongweibing shidai fengyun renwu koushu lishi [Recollections and reflections: Oral histories of prominent Red Guards], vol. 1, ed. Mi Hedu (Hong Kong: Zhongguo shuju youxian gongsi, 2011), 34; Bu Weihua, “Qinghua fuzhong hongweibing chengli shimo" [The story behind the founding of Qinghua High School Red Guards], Zhonggong Dangshi Ziliao 77 (1999): 113; Yan Yangsheng, "Qinghua fuzhong hongweibing yibaitian" [One hundred days of Qinghua High School Red Guards," Jiyi 10 (2008): 19.

72. Yan Yangsheng, "Qinghua fuzhong hongweibing yibaitian," 15; Zhong Weiguang, "'Qinghua fuzhong hongweibing xiaozu' dansheng shishi" [The birth of Qinghua High School Red Guard group]," Beijing Zhichun $10(1996): 9$ 
only to "obey the routine order." ${ }^{73}$ This fledgling rebel ethos would eventually predispose students to clash with the party bureaucracy.

Initially, these students bonded together as an informal group because of their common disagreement with the school party authority's managerial approach to Communist Youth League recruitment and selection of classroom leaders. ${ }^{74}$ Gradually, they began to elevate this disagreement to the level of revolutionary struggle. This elevation was undoubtedly related to the heightened ideological rhetoric during the debate on the historical play Hai Rui Dismissed from the Office since November 1965 and its increasing politicization. ${ }^{75}$ Yet, it was students' interpretive agency, and not Mao's direct intervention, that propelled them into action. Bu Dahua, one of their leaders, recounted how they forged a new interpretation of their own role in this context. On April 30, sixteen of them went together for a three-day spring outing. On the trip, they eagerly discussed the escalation of the Hai Rui debate that led to the recent purge of the leadership in Beijing municipal party committee and felt that a hoped-for revolution was coming:

I felt my body seemed to be possessed by many revolutionary souls: there were Zou Rong who eulogized revolution; Chen Tianhua who didn't hesitate to lay down his life for the revolution; Lu Xun who grasped "his pen as a sword"; Lenin when he studied in Kazan University; Mao Zedong who zealously expressed himself in Aiwan Pavilion; and even Russian Decemberists. . . Ideal, illusion, fantasy, and reverie were all swirling in my mind. . . . Before going back to campus, we stood at the mountain pass, reciting in unison a poem Mao Zedong wrote in his youth:

Alone I stand in the autumn chill,

Watching the Xiang River flow north still ...

The sacrificial passion and heroic aura this poem invoked filled our eyes with tears. Sincere and solemn, we seemed back in the May Fourth era. ${ }^{76}$

With "many revolutionary souls" possessing their bodies, these students began to completely identify themselves with past revolutionary heroes. Empowered by

\footnotetext{
73. Qinghua High School Red Guards, eds., Wen cangmang dadi, shuizhu chenfu: Hongweibing dazibao xuanbian [Who masters the ebb and flow of the boundless earth: Selections of Red Guards big-character posters] (Beijing: September 1966), 17-18. See also Luo Xiaohai, "Xu" [Introduction], in Song Bolin, Hongweibing xingshuailu [The rise and fall of the Red Guards: The diary of a Qinghua High School Red Guard] (Hong Kong: Desai chuban gongsi, 2006), 16; Bu Weihua, "Qinghua fuzhong hongweibing chengli shimo," 99.

74. Many of them shared similar "red" family backgrounds. See Andreas, "Battling over Political and Cultural Power during the Chinese Cultural Revolution." For the question of family social backgrounds, see the discussion below.

75. Bu Weihua, "Qinghua fuzhong hongweibing chengli shimo," 99.

76. Bu Dahua, “Hongweibing zhiqi," 6.
} 
this identification and by their interpretation of an increasingly conducive political climate, they left with a sense that "our life will no longer be ordinary and plain."77 In the next three months, their style of mobilization would clash with the bureaucratic mobilization, first of the school party committee and then of the work team.

The Cultural Revolution is conventionally understood to begin on May 16, 1966, when an enlarged meeting of the CCP Central Committee passed a directive that Mao had prepared. The directive criticized high-ranking official Peng Zhen, who Mao believed had accommodated the ideological assault in the Hai Rui play, and vowed to purge revisionists like him in this "Great Cultural Revolution." The directive elevated the Hai Rui debate to a political purge. Yet, it was then only circulated in the upper and middle party echelons and did not get publicized until one year later.

Moreover, what this narrative papers over is precisely the changing meaning of "cultural revolution" that dialogic struggle between Mao, party officials, and students brought about after May 16. The May 16 directive was essentially the continuation of the ideological offense that Mao had invested himself in within the cultural spheres since 1964, when he called for a "cultural revolution." The directive simply elevated it into a political purge. This document did not hint at any form of mobilization different from the kind of loyalty fortification campaigns that typically accompanied political purges in Stalinist polities_calling on the people to pledge support for the purges. Such was the case when, on May 4, the Youth League leadership called on students and youth to participate in the Cultural Revolution. ${ }^{78}$ In practice, party officials interpreted the Cultural Revolution in light of the Anti-Rightist campaign in 1957 for its combination of ideological offense and political purge. Their approach, however, clashed with students, not so much for its goal of purge as for its means, as students were looking for a genuine revolutionary role for themselves to play.

Hence, when the principal of Qinghua High School called on students to participate in the Cultural Revolution on May 10, he instructed students to "attack wherever the Party points to." Students like Bu Dahua, however, accused the Party committee of being "fake revolutionaries," for it only wanted students "to monotonously fire at anti-Party persons without bringing their own ideas" and without "big debates and big criticisms." ${ }^{79}$ In response, the Youth League secretary at the school warned them of the dire consequences of their action, citing precedents in 1957 when students raised criticisms of party committees and ended up being labeled as rightists. ${ }^{80}$

77. Bu Dahua, "Wosuo zhidao de hongweibing," 31.

78. People's Daily, May 4, 1966.

79. Bu Weihua, "Qinghua fuzhong hongweibing chengli shimo," 101.

80. Bu Dahua, "Wosuo zhidao de hongweibing," 31; Bu Weihua, "Qinghua fuzhong hongweibing chengli shimo," 103. For similar scenarios, see Wu, The Cultural Revolution at the Margins, 149. 
Her intimidation, instead, provoked students' further resistance. As both the party committee and militant students tried to collect "black materials" against the other side, other students were forced to choose between them. The dissenting militants now agglomerated into a few dozen students. The school authority declared that whoever continued to target the school administration was an antiparty person. Since the school leadership had already treated them as a heretical group, on May 29, core individuals met secretively to form an organization- “Red Guards," adopted from a pen name that one of them had used. The second day, they held an assembly in which "a rumored 'directive' from Mao, full of passion, was read: 'How precious and important the next few decades will be for the future of the motherland and the fate of the humanity.... Youth of this generation will turn our poor motherland into a great socialist country and will directly participate in the battle of burying imperialism. . . Chinese youth with will and ambition must fight for life in order to accomplish our great historical mission.' Many present burst into tears and even out crying." ${ }^{81}$ This rumored "directive," which was misattributed to Mao yet spread widely, was very likely students' collective invention and epitomized the misrecognition of their own agency: they projected it onto Mao. ${ }^{82}$

The broadcasting of the big-character poster by seven staff members at Beijing University attacking the university leadership on June 1 strongly boosted Red Guards' morale. ${ }^{83}$ From June 2 on, they posted a series of big-character posters criticizing the high school's party leadership. They created a big stir but were still outnumbered by posters defending the party committee. In the following days, as like-minded students from other schools poured in the campus to support the Red Guards, they also adopted their name. "Red Guards," hence, quickly diffused to other campuses. ${ }^{84}$ The conflict came to a ten-hour standoff when the school locked out Red Guard supporters from other schools who tried to fight their way in.

On that night, the Party Center sent in a work team to replace the school party leadership and control the situation, as was happening on other campuses too. The work team immediately declared their support for Red Guards. The situation turned around, and many from the Red Guards were elected onto the newly formed Revolutionary Committee, which functioned under the work team's leadership. However, as the work team tried to keep Red Guards under control and particularly to

81. Luo Xiaohai, "Xu," 19.

82. For the appearance elsewhere of this rumored directive, see You Xilin, "Wenge jingkuang pianduan," 2.

83. In terms of grassroots mobilization, the big-character poster incident at Beijing University on May 25 was less a breakthrough than the founding of Red Guards on May 29.

84. Bu Dahua, "Wosuo zhidao de hongweibing," 34. 
absorb them into the Youth League organization, the Red Guards proved intractable. ${ }^{85}$ Their relationship with the work team began to sour.

On June 23, the Red Guards managed to secure a secret weapon when they found a quotation from a speech of Mao during the Yan'an revolutionary era that had been omitted in its post-1949 editions: "rebellion is justified!" ${ }^{86}$ On the following day, they declared this revolutionary message, without directly quoting Mao, in a big-character poster titled "Long Live the Revolutionary Spirit of Rebellion." ${ }^{87}$ The work team, in keeping with its spirit of bureaucratic control and having no knowledge about this revolutionary doctrine, fired back fiercely by claiming: "Now, the Red Guards have exposed their counterrevolutionary true face. Why do you rebel? Whom do you rebel against? Need you rebel when striving for socialism?" ${ }^{88}$ Defenders of work teams in Qinghua High School and Qinghua University overwhelmed the Red Guards, whose heretical poster was now labeled as reactionary by the Party Center. ${ }^{89}$

However, in their next poster on July 4, they revealed Mao's quotation and claimed that, according to Mao, "to rebel and struggle is the true strife for socialism." By invoking this saying of Mao from the revolutionary era, the Red Guards effectively severed the ideological linkage between Mao and the party bureaucracy and undermined the legitimacy of the elaborate apparatus of social control under its aegis. The doctrine then became a rallying point for student rebels citywide and, later on, nationwide. At Qinghua High School, it severely demoralized the work team, which then tried to negotiate with the Red Guards but failed. ${ }^{90}$ On July 28 , during a gathering of Beijing students where members of the Central Cultural Revolution Group declared the recall of work teams, Qinghua High School Red Guards managed to approach Jiang Qing, Mao's wife, and petition their case to her and Mao. ${ }^{91}$ On August 1, on the day of the opening vignette of this article, Mao wrote a letter to Red Guards, openly declaring his support for them and his recognition

85. Liu Jin, "Hongweibing yundong xingqi qinliji" [My personal witness to the rise of the Red Guard movement], Yanhuang Chunqiu 5 (2008): 32; Bu Dahua, "Wosuo zhidao de hongweibing," 36-37; Yan Yangsheng, "Qinghua fuzhong hongweibing yibaitian," 21.

86. Bu Dahua, "Hongweibing zhiqi," 11-12.

87. Qinghua High School Red Guards, eds., Wen cangmang dadi, shuizhu chenfu: Hongweibing dazibao xuanbian, 6 .

88. Bu Dahua, "Hongweibing zhiqi," 12.

89. Song Bolin, Hongweibing xingshuailu, 88-89; Yan Yangsheng, “Qinghua fuzhong hongweibing yibaitian," 21-22.

90. Bu Dahua, "Hongweibing zhiqi," 13-14; Bu Weihua, "Qinghua fuzhong hongweibing chengli shimo," 120; Yan Yangsheng, “Qinghua fuzhong hongweibing yibaitian,” 22.

91. Bu Dahua, "Hongweibing zhiqi," 15-16; Yan Yangsheng, "Qinghua fuzhong hongweibing yibaitian," 23. 
of mass organizations independent from the party hierarchy. Thus did he seal his "telepathy" with Red Guards. ${ }^{92}$ With Mao's blessings, the Red Guard Movement diffused nationwide in their toppling of the educational authority and Party establishment.

\section{ETHOS AND INTERESTS IN DIALOGIC STRUGGLE}

The case study of the Qinghua High School Red Guards further demonstrates that (1) students had already cultivated predispositions for militant mobilization before the Cultural Revolution; ${ }^{93}$ (2) such predispositions resulted from their agentic disarticulation of the contradictions between ideological legitimation and bureaucratic routinization; (3) such predispositions for disruptive mobilization brought them into antagonism with the party hierarchy's bureaucratic control (following the 1957 pattern); (4) in clashing with the Party's style of mobilization, they contributed to defining the unfolding situation ("rebellion is justified") and transforming an initially bureaucratically organized purge into a frontal assault to the party bureaucracy.

As the first Red Guard organization, the Qinghua Red Guards by no means represented average students. Rather, they highlighted the ideological contradictions they experienced and the social process through which such contradictions were disarticulated and rearticulated in Cultural Revolution activism. Nevertheless, the fact that the name and the style of the Red Guards quickly diffused to other campuses suggests a more general pattern. Furthermore, the predispositions for militant mobilization were rather ubiquitous among students, even though the first Red Guards, like the Qinghua Red Guards, were mostly children of "red" families, especially those of revolutionary cadres. ${ }^{94}$

Despite this shared ethos, there were good reasons why "non-red" students did not actively participate initially. ${ }^{95}$ First, they looked on from the sidelines because it was riskier for them to challenge the party hierarchy than it was for students of "red classes." 96 In fact, some "non-red" students at Qinghua High School withdrew

92. Bu Dahua, "Hongweibing zhiqi," 9.

93. For the extension of Bourdieusian concept of habitus to social movements, see Nick Crossley, "From Reproduction to Transformation Social Movement Fields and the Radical Habitus," Theory, Culture $\theta$ Society 20, no. 6 (2003): 43-68.

94. Yan Yangsheng, "Qinghua fuzhong hongweibing yibaitian," 19.

95. He Shu, "Yikuai jiyou yanjiu jiazhi de ‘huohuashi': Du 'hongweibing xinghuailu' yougan" [A "living fossil" that is extremely valuable for research: Comments on the rise and fall of the Red Guards], China News Digest 503 (2006), accessed July 19, 2015, http://www.cnd.org/CR/ZK06/cr337.gb.html\#3.

96. Bu Dahua, "Wode hongweibing jingli" [My Red Guard experience], 2011, accessed July 9, 2015. http://www.difangwenge.org/read.php?tid=6443. 
at this stage. ${ }^{97}$ Second, they were discouraged from participation and, after August, were often victimized by students of "red classes," who saw a hereditary connection between their revolutionary parents and themselves and considered many non-red students unreformed for revolution. This was what happened to novelist Hu Fayun: "Although in the beginning, I was also very excited and enthusiastic, as if we were back to the scenes of the May Fourth era, the Anti-Japanese War, and the December Ninth Movement, just like what I have read from novels like Song of Youth. But I soon discovered that this exciting and challenging revolution, this revolution which I had longed for in years, was not my revolution." 98

It was not until after October, when these two inhibiting factors were removed, that non-red students reclaimed their "rights to be revolutionaries." 99 Before that point, Walder is right to claim that early activism was confined to students of impeccable backgrounds. ${ }^{100}$ Class did not, as the social interpretation claimed, play a role in early factional formation. But it did function as an exclusionary mechanism-especially in high schools. Later, when non-red students participated, it emerged as a dividing issue in factionalism. ${ }^{101}$

Notwithstanding their different conclusion about the influence of class in early factional formation, both the social and political interpretations only consider actors as instrumental calculators. Coupled together with the teleological narrative about the cause of the Cultural Revolution, they suppress the question of its becoming by overlooking the dialogic struggle in the process. As Charles Tilly said about the sustained interactions in social movements, "real social movements always involve a symbolically constrained conversation among multiple actors, in which the ability to deploy symbols and idioms significantly affects the outcome of the interaction." 102 What the Red Guards did was to precisely deploy and retool symbols, idioms, and repertoires enmeshed in the hegemonic discourse of the pre-Cultural Revolution party-state, with the effect of gaining Mao's support and antagonizing his staff. The dialogic struggle that I focus on here highlights the temporally embedded and structurally transformative agency through which actors brought forth

97. Zheng Yi, “Qinghua fuzhong, hongweibing yuwo" [Qinghua High School, Red Guards, and me], Beijing Zhichun 11 (1996): 29; Zhong Weiguang, "'Qinghua fuzhong hongweibing xiaozu' dansheng shishi," 11. For exceptions, see Tao Zheng, "Wo ben suihe" [I am easygoing], in Nage niandai zhongde women [We were in that era], ed. Zhe Yongping, vol. 1 (Hohhot: Yuanfang chubanshe, 1998), 108-15; Zhang Lifan, "Wo de 'dizhongxing' shenghuo jianwen" [My 'pariah' life observations], Duzhe Wenzhai 1 (2011): 47-53.

98. Hu Fayun "Hong luyi" [Red Lu Xun art troupe], in Xu Youyu, 1966: Women nayidai de huiyi, 206. 99. Zhong Weiguang, "'Qinghua fuzhong hongweibing xiaozu' dansheng shishi," 15.

100. Walder, "Beijing Red Guard Factionalism."

101. Andreas, "Battling over Political and Cultural Power during the Chinese Cultural Revolution."

102. Charles Tilly, Big Structures, Large Processes, Huge Comparisons (New York: Russell Sage Foundation, 1984), 31. 
the collective outcome of the Cultural Revolution. Paying attention to these dynamics does not deny that individuals are strategic rational actors. Rather, as James Jasper points out, making strategic choices and interactions is a culturally constituted and constitutive process. ${ }^{103}$ Looking at dialogic struggle enables us to chart out the ongoing structural transformations in which individual understanding of their interest is anchored and realigned. I summarize the contrast between the existing approaches and my approach in table 1 .

\section{CONTEXTUALIZING MAO}

The conventional explanation that Mao launched the Cultural Revolution in order to attack the party officialdom entails a very strong assumption that is insufficiently substantiated by historical evidence: Mao, whether a hero or villain, had formulated a master plan beforehand that he strategically played out. By contrast, the dialogic struggle perspective posits that his goals were more like Dewey's notion of "ends-in-view," ever adapting to changing relational contexts and situational exigencies. ${ }^{104}$ It shifts our focus to the actual organizational dynamics of the Cultural Revolution's emergence instead of relying on the speculation, barely supported by extant evidence, that students did exactly what Mao had orchestrated and expected them to do. While the relationship between Mao and the Cultural Revolution would warrant a separate study, it behooves me to clarify briefly how the dialogic struggle perspective helps contextualize Mao's motivation and action.

The existing literature provides two accounts of Mao's motivation: he was driven either by a vision of reviving revolutionary enthusiasm or by a shrewd design of egoistic struggle to take power back from his lieutenants. ${ }^{105}$ Both accounts, which are not necessarily mutually exclusive, construct a narrative of his motivation based largely on the outcome of this process. Because Mao had a record of rationalizing unintended consequences by his alleged intention (an example of which is his justification of the Hundred Flowers movement in 1956-57 as an "open conspiracy" to purge Rightists), such constructions should be taken with a grain of salt. What historical evidence does indicate is his growing frustration with the entrenchment of the party officialdom since 1964, many of whom he suspected had colluded with "bourgeois" intellectuals to erode his personal authority (through the latter's insinuating and sarcastic works) and the party's revolutionary commitment.

103. James M. Jasper, “A Strategic Approach to Collective Action: Looking for Agency in SocialMovement Choices," Mobilization: An International Quarterly 9, no. 1 (2004): 1-16.

104. Hans Joas, The Creativity of Action (Chicago: University of Chicago Press, 1996).

105. For the second interpretation, see Simon Leys, The Chairman's New Clothes: Mao and the Cultural Revolution (London: Allison \& Busby, 1981). 


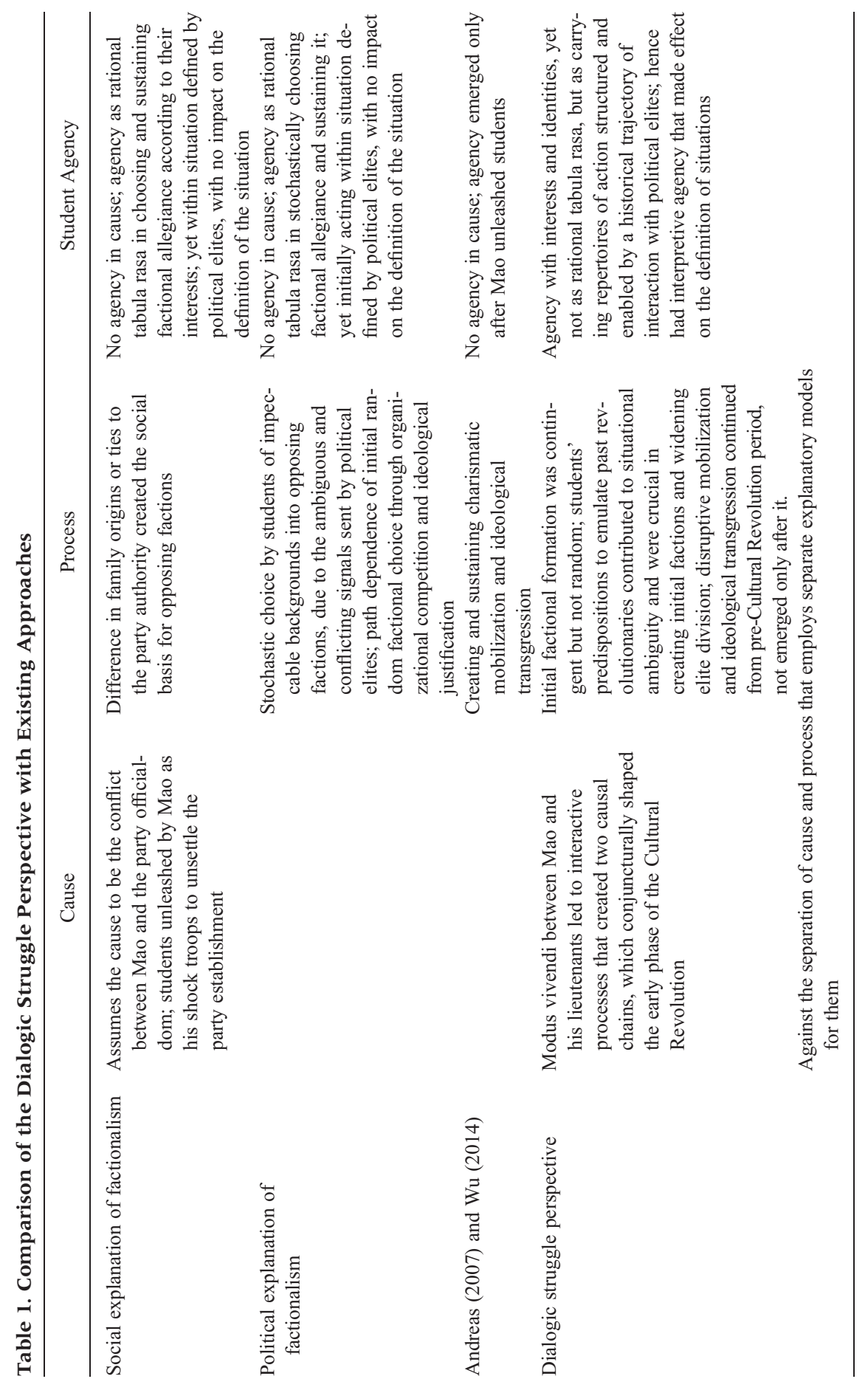


His frustration should be understood in the context of modus vivendi after the legitimacy crises, when Mao retreated to the second front in charge of ideological guidance, while his lieutenants such as Liu Shaoqi and Deng Xiaoping took over the first front. Two consequences followed from that arrangement. On the one hand, his image within the party's ideological makeup grew even larger when his actual organizational control outside of the ideological domain had shrunk. The production of the song-and-dance epic The East Is Red in 1964 and its release as a film in 1965 were especially instrumental in apotheosizing Mao as the embodiment of the Chinese revolution, the will of the masses, and the correct line of the party all at the same time. On the other hand, as he was now shielded from the onerous complexity of running the party administration, he was increasingly inclined toward ideological consistency and polemical coherence, which would have taken much less priority had he not stepped down from the first front. After the Sino-Soviet debate in 1962, Mao branched out to diverse ideological fields such as Marxist historiography, literary criticism, and philosophy, which all converged into his ideological offense against Hai Rui Dismissed from Office. It is in this context that we should understand why Mao grew increasingly frustrated with the party bureaucracy, especially after the Four Cleans campaign in $1964 .{ }^{106}$

Yet, his frustration did not itself translate into a coherent master plan to unsettle it, even though it helps explain why he subsequently embraced student rebellion. What he did initiate was a purge involving party officials, particularly those in cultural and educational domains. The idea that Mao directly and intentionally incited students to attack the party officialdom grossly misunderstands how politics actually worked on the eve of the Cultural Revolution, when a vast and highly organized party bureaucracy penetrated deeply into the body politic and every policy initiative went through this system. ${ }^{107}$ Indeed, the party bureaucracy executed Mao's purge initiative quite faithfully, only to be baffled by students' recalcitrant attempt to make it into their own revolution. During this crucial period, Mao was travelling in the provinces until his return to Beijing on July 18, and little evidence has emerged indicating his state of mind, except a letter to his wife Jiang Qing on July 8 in which, after learning the chaos that student mobilization had wrought on campuses, he expressed his delight at this "great chaos under the heaven," which he believed would eventually lead to the "great peace under the heaven." Counterfactually speaking, without students' rebellious thrust and the conflict between

106. Dittmer, Liu Shao-Chi and the Chinese Cultural Revolution; MacFarquhar, The Origins of the Cultural Revolution.

107. Walder, "Cultural Revolution Radicalism," and "Ambiguity and Choice in Political Movements." 
students and party officials regarding the means and meaning of the Cultural Revolution, it might have been just another instance of ideological offensive cum political purge, like the Anti-Rightist campaign in 1957.

It is also in this larger context that we should understand why Mao soon abandoned much of the party bureaucracy to embrace student rebellion: since the early 1960s, he had pursued an ideological consistency, which his party could not live up to, yet which the students seemed to express with impressive clarity. Like students, he experienced intense contradictions too: the decoupling between ideological consistency and bureaucratic complexity. This constituted, from his end, the basis of the "telepathy" between Mao and the students that Bu Dahua has spoken of.

In endorsing student rebellion, Mao recast party officials' action as revisionist suppression of mass movement and framed the students' action as part of his struggle against revisionism. In late 1966 and early 1967, he further articulated the twoline struggle thesis, reframing the Cultural Revolution as "a form, a method, to arouse the broad masses to expose our dark aspect openly, in an all-round way and from below." ${ }^{108}$ The thesis crucially locked in students' misrecognition of their own agency: while it projected a sense of consistency to Mao's rather situationally embedded actions, it was also enthusiastically accepted by students as it conferred legitimacy upon their earlier actions. It was a narrative rationalization of the new political landscape whereby the convergence between Mao and students had been sealed and the ideo-

logical linkage between Mao and the party hierarchy had been shaken. In short, the thesis itself was an outcome of the conjunctural causal process dissected in this study. In this sense, students' interpretive agency in shifting the meaning of the Cultural Revolution remained captive to the Maoist aura. Their rebellion did not diverge from Mao's campaign of ideological purge but infused it with new repertoires. Yet, their rebel ethos paved the way for the "unruly margins," as Yi-ching Wu put it, that emerged when Cultural Revolution activism came into full force and eventually for the heretical ideas that blossomed in the 1970s. ${ }^{109}$

\section{CONCLUSION}

Returning to the opening vignette of this article, the struggle over interpretation was also in full display here. While Mao acknowledged contingency in the unfolding Cultural Revolution at the factual level, he nevertheless used historical necessity to account for, envelop, and tame it. His power in this unfolding event hinged upon his success in making his interpretation prevail over those of his colleagues,

108. Mao Zedong, Mao Zedong sixiang wansui, 288.

109. Wu, The Cultural Revolution at the Margins. 
which he accomplished when he pushed through the Sixteen Points. It is this politics of interpretation that this article has been concerned with.

The existing literature has hidden this dynamic politics of interpretation. By temporally dividing the cause and process of the Cultural Revolution into two separate questions, it complements the teleological narrative of elite conflict with instrumental rational notions of individual agency in factional formation. This leaves two contradictory images of the Red Guards seemingly in harmony with each other: on the one hand, they were ideological zealots who were easily schemed into an elite-designed power struggle; on the other, they were rational choice actors looking after their own instrumental interests. ${ }^{110}$ What is missing is a robust analysis of their agentic appropriation and articulation of symbols, rituals, idioms, and artefacts. What the dialogic struggle perspective does here is address (1) how students' militant heroism came about and (2) why it mattered in shaping the Cultural Revolution as we know it.

(1) I show that students' militant heroism resulted not from straightforward indoctrination, but from their active appropriation in response to the severe contradictions that were created by official ideological campaigns. The Red Guards were not alone in such appropriation of hegemonic ideology. Their emulation of past revolutionaries echoed Marx's vivid account of how French revolutionaries of 1848 spoke and acted after the fashion of the revolutionaries of $1789 .{ }^{111}$ Similarly, nineteenth-century English cotton spinners actively appropriated and rearticulated mill owners' dominant discourses to forge their own movement. ${ }^{112}$ One also thinks of how Polish workers' appropriation of the official discourse of the "radiant past" of the proletariat informed the Solidarity movement. ${ }^{113}$ As Swidler put it, "It is the re-appropriation of larger, culturally organized capacities for action that gives culture its enduring effects." ${ }^{114}$ As active operators of cultures instead of "cultural dopes," in-

110. For the former, see Chan, Children of Mao. Guobin Yang's work is attentive to both aspects, even though he has not explicitly tackled the tension between them. See Guobin Yang, "The Liminal Effects of Social Movements: Red Guards and the Transformation of Identity" Sociological Forum 15, no. 3 (2000): 379-406; Guobin Yang, The Red Guard Generation and Political Activism in China (New York: Columbia University Press, 2016). Xiaowei Zheng's work also highlights the role of "passion and conviction" in initially propelling student rebels, see her "Passion, Reflection, and Survival: Political Choices of Red Guards at Qinghua University, June 1966-July 1968," in The Chinese Cultural Revolution as History, ed. Joseph Esherick, Paul Pickowicz, and Andrew Walder (Stanford, CA: Stanford University Press, 2006), 33.

111. Karl Marx, The Eighteenth Brumaire of Louis Bonaparte (Moscow: Progress Publishers, 1934).

112. Steinberg, "The Talk and Back Talk of Collective Action."

113. Michael Burawoy and János Lukács, The Radiant Past: Ideology and Reality in Hungary's Road to Capitalism (Cambridge: Cambridge University Press, 1992); Michael Burawoy, "Marxism after Communism," Theory and Society 29, no. 2 (2000): 166.

114. Ann Swidler, "Culture in Action: Symbols and Strategies," American Sociological Review (1986): 283. 
dividuals manifest their agency partly by navigating the internal relations and contradictions in their structurally afforded cultural repertoires. ${ }^{115}$

(2) I clarify that revolutionary heroism mattered because it introduced a separate causal force that intersected with a typical Stalinist purge mechanism-the 1957 template-and spawned an emergent process whereby the students' clash with the party bureaucracy changed the meaning of "cultural revolution" and widened elite division. By dislodging teleological construction, the dialogic struggle perspective introduced in this article renders visible the state of struggle over interpretation in transformative historical events. In this rendition, paying attention to historical contingency not only does not compromise structural inquiry, as deterministic thinking would assume, but helps to shed light on hidden structural affordances and build up more robust explanations of social change. ${ }^{116}$

The Cultural Revolution is a deeply polarizing issue in the Chinese society. Any causal claim about its dynamics carries serious political and moral connotations. The Mao-era official line claimed that party officialdom was gradually estranged from the masses and the original revolutionary ideals embodied by Mao, who then mobilized the masses to rectify party officials; the post-Mao official verdict, on the other hand, claims that Mao, misguided by a handful of power-hungry leftists, was erroneous in calling on the masses to attack innocent party officials and intellectuals; there are also unofficial narratives, which cast Mao as a villain who "launched" the Cultural Revolution for his egoistic purpose and plunged the country into chaos, human rights abuses and destruction. ${ }^{117}$ Notwithstanding their different moral evaluations, they largely share the same narrative structure derived from the twoline struggle thesis that Mao himself had built up. Decades of historical research have enormously complicated these moral tales of opposing orientations but still have not fundamentally shaken their teleological cornerstone. By explicitly unsettling this foundation and addressing the question of becoming, this article hopes to contribute to the ongoing reflection on political and moral responsibility in collective action.

115. For critique of "cultural dopes," see Harold Garfinkel, "Studies of the Routine Grounds of Everyday Activities," Social Problems 11, no. 3 (January 1, 1964): 225-50.

116. Ermakoff, "The Structure of Contingency"; Reed, "Between Structural Breakdown and Crisis Action."

117. The CCP Central Committee, "Resolution on Certain Questions in the History of Our Party since the Foundation of the People's Republic of China" (June 27, 1981), Beijing Review, no. 27 (July 4, 1981), 20-26. For a survey of various evaluations in post-Mao era, see Qin Hui, "Dui wenge de sizhong pingjia" [Four verdicts on the Cultural Revolution], 2014, accessed August 3, 2016, http://www.aisixiang.com/data /80779.html. 